\title{
Pseudepigraphic Paulines in the New
}

\section{Testament}

\author{
Eduard Verhoef ${ }^{1}$ \\ Maartensdijk (The Netherlands) \\ Research Associate: University of Pretoria
}

\begin{abstract}
In order to verify the presence of pseudepigraphic epistles in the New Testament, scholars have often argued that followers of a famous philosopher, such as Pythagoras or Plato, wrote pseudepigraphic documents. This argument presumes that pseudepigraphy was an accepted phenomenon in antiquity and that the writing of epistles under someone else's name was socially not offensive. In this article, this presumption is questioned. The article shows that writers could be banished or put to death if it was the intention of their writings to deceive their audience as far as the identity of the author thereof. As epistles are distinguished from short stories or poems, writings which were written with the intention of deceiving their readers should be set apart from those without such an intention. In view of this distinction the article establishes categories of "Pauline" epistles in the New Testament. The aim is to argue that there are indeed epistles which intended to deceive their readers with regard to "Pauline" authorship. The legitimacy of these epistles would have been rejected on account of their pseudepigraphic nature.
\end{abstract}

\section{THE PROBLEM}

The phenomenon of pseudepigraphy is a very interesting and frequently discussed topic in studies about New Testament epistles. In these studies different opinions about pseudepigraphy can be found. But it is remarkable to

\footnotetext{
${ }^{1}$ Dr Eduard Verhoef (Maartensdijk, the Netherlands) participates in the research project "Biblical Theology and Hermeneutics", directed by Prof Dr Andries G van Aarde, Department of New Testament Studies, Faculty of Theology, University of Pretoria). In April 2003 and in July 2003 Dr Verhoef and Prof Van Aarde shared workshops at a meeting of New Testament scholars from the Netherlands and Belgium in Zeist, the Netherlands, and the SBL International Meeting at the University of Cambridge. This paper was presented in Cambridge on 23 July 2003. Drs J W van Arenthals' helpful comments is hereby acknowledged with appreciation.
} 


\section{Pseudepigraphic Paulines in the New Testament}

note that scholars focusing on this topic can be roughly divided into two categories:

- $\quad$ Those who argue that we do not have any pseudepigraphic epistles in the New Testament and who contend that pseudepigraphy was not an accepted phenomenon in the time of the formation of the canon.

- $\quad$ Those who, on the contrary, are of the opinion that we do have pseudepigraphic epistles in the New Testament and who argue that the people of that particular era did not have any problem with the phenomenon of authors writing epistles under another person's name.

This remarkable division leads me to suspect that spurious motives played a role in their arguments, since, according to these scholars, the question whether or not pseudepigraphy was an accepted phenomenon, depends on the question whether we have pseudepigraphic epistles in the New Testament. Elsewhere, I have argued that some of the New Testament epistles are pseudepigraphic. ${ }^{2}$ In this article, I wish to discuss the question of how to assess these pseudepigraphic documents against the background of other pseudepigrapha of that era.

\subsection{Speyer's study}

In 1971, Wolfgang Speyer published a most instructive study in this regard: Die literarische Fälschung im heidnischen und christlichen Altertum. Speyer (1971:175) argued that for the sake of a document's reliability, it was of great importance to mention the name of the author thereof. The mentioning of the author's name would enhance a document's authority. The way in which Paul stressed that he himself was the author of certain epistles, is indicative of the fact that he considered it of great importance that the readers should be convinced about the authenticity of his epistles (see 1 Cor 16:21; GI 6:11). Scholars such as

\footnotetext{
${ }^{2}$ I count the following "Pauline" epistles as belonging to this group: Ephesians, Colossians, 2 Thessalonians, 1 and 2 Timothy and Titus (see Verhoef 1996:28-35; 2002:8-12; [2003]).
} 
Origenes, Eusebius, Jerome and others used style and vocabulary to distinguish between authentic documents and forgeries (Speyer 1971:182).

In the case of possible pseudepigraphic documents in the New Testament, according to Speyer (1971:176-177) it is often argued, that we are not confronted with forgeries, but with the literary convention of writing documents under the name of a famous teacher. Speyer repudiated this point of view. He argued that during the first three centuries of our era it was not very suitable for Christian authors to write documents merely with a literary purpose. This implies that, if Christian authors published epistles under another person's name, these documents should in general be labeled as forgeries (Speyer 1971:178). But if research led to the conclusion that an epistle was inauthentic, it was according to Speyer, not accepted. He provides several examples of Christian authorities which acted with great caution in order to prevent reading pseudepigraphic documents in church (Speyer 1971:180-181; cf Ellis 2001:22-23). Similarly, a text such as 2 Th 2:2; 3:17 show that the author of this epistle reckoned in any case with the existence of pseudepigraphic writings. If he himself wrote under someone else's name, which presumably is the case in this instance, then these sentences are intended to place his epistle beyond all suspicion.

According to Speyer, the content of a document also served as a very important criterion, perhaps even more important than authorship. An epistle needed to be orthodox if it were to be accepted in the church and should be in line with the undisputed epistles and gospels. The case of bishop Serapion is well-known: he repudiated the Gospel of Peter only after he had discovered the heresies preached therein (Eusebius, Historia Ecclesiastica VI, 12). In this case it is evident that more attention was paid to orthodoxy than to authenticity. We should nevertheless be cautious in dealing with this criterion. For it should be established which opinion was thought to be orthodox. Did it mean being "in line with the gospels" or being "in line with the Paulines"? Be that as it may, this criterion did not prevent the epistle of James of being accepted in the canon in spite of differences between this epistle and the Paulines. The particular attention for orthodoxy could in some cases result in the appreciation of documents 
thought to be orthodox, but which indeed were pseudepigraphic (see the remarks by Eusebius, Historia Ecclesiastica I, 13,1-22 [cf Speyer 1971:201] on the correspondence between Jesus and Abgar, king of Edessa). Eusebius thought these letters to be authentic. ${ }^{3}$ Before a document was accepted for reading in a church, it could also be asked whether such a writing had been continuously read in the apostolic church (Speyer 1971:187). Such continuity would be in favour of a document. In light of all the data, it is clear that we cannot in advance exclude the possibility of pseudepigraphic documents occurring in the New Testament. In light of all the data it is clear that we cannot exclude in advance the possibility of pseudepigraphic documents occurring in the New Testament. The authorities making the decisions did not always expose the pseudepigraphic character, though they did condemn writing a letter with the intention of deceiving the readers regarding its the authorship (Speyer 1971:180). ${ }^{4}$

\section{$1.3 \quad$ Recent studies}

The books and articles published afterwards on this topic ${ }^{5}$ have often been obscured by faulty arguments. Preceding a broad discussion, Meade (1986:2) said: "the question is how forged documents can serve as vehicles of inspired religious truth." He is of the opinion that they can indeed not do so! Consequently in his conclusion, Meade did not want to speak about forgeries, but speaks about epistles which meet "the recurring need to actualize a tradition for a future generation" (Meade 1986:215). It is evident that his conclusions have been influenced by his preliminary remarks.

We can clearly see that many scholars experienced a problem with the occurrence of pseudepigraphic epistles in the New Testament. For one reason or

\footnotetext{
${ }^{3}$ Eusebius, Historia Ecclesiastica I, 13,3: Jesus ' considered him worthy of a letter of his own.

${ }^{4}$ Cf Klauck (1998:303): "Man darf nicht [...] behaupten, daß Pseudepigraphie in der Antike ein allgemein verbreiteter und anerkannter Vorgang gewesen sei, an dem niemand mehr Anstoß nahm."

${ }^{5}$ I will limit my discussion to some studies about pseudepigraphy in relation to the New Testament.
} 
another, they are reluctant to acknowledge the existence of pseudepigraphic epistles in the Bible. But, as this phenomenon could not be denied, they therefore tried to extenuate it. ${ }^{6}$ Recently Marshall (1999) wrote a commentary on the Pastorals. He admitted that we are dealing with an author "writing in another person's name" (Marshall 1999:84). But he continued with the phrase "without intent to deceive". Marshall $(1999: 84,92)$ proposed to henceforth use the word "allonymity" instead of "pseudonymity". He argued that the Pastorals were intended "to give Pauline backing to Timothy and Titus [...] in their work of calling the congregations back from false teaching" (Marshall 1999:92). But how could these letters be of assistance to Timothy and Titus in their struggle against "false teaching" if these epistles were known to have been "produced in a group which included Timothy and Titus themselves" (Marshall 1999:92)? These epistles could only have "Pauline" authority and influence if they were really thought to have been written by Paul himself.

Such an approach does not allow a proper discussion of pseudepigraphy. The discussion seems to be dominated by the desire to avoid negative comment on the epistles of the New Testament. But we should try to study this phenomenon without such prejudices.

\subsection{Another approach}

In the knowledge that we have pseudepigraphic epistles in the New Testament, I wish to deal with the following three points:

- $\quad$ The phenomenon "pseudepigraphy" should be surveyed shortly.

- The question as to which category the pseudepigraphic Paulines belong to, must be posed.

- We should establish whether pseudepigraphic epistles were acceptable in the churches.

\footnotetext{
${ }^{6}$ Brox (1969:61) states it as follows: "Zwar hat es auch im Altertum literarische Fälschungen aus unredlichen Motiven [...] gegeben, doch gehört die biblische Pseudepigraphie zu jenem Zweig dieser Literaturgattung, für die der Begriff "Fälschung (Fälscher)" ausschließlich als literarische Kategorie anwendbar ist [...]" (cf Collins 1988:252-254).
} 


\subsubsection{A short survey of the phenomenon "pseudepigraphy"}

The label of "pseudepigraphy" is used in respect of rather different documents, written for divergent purposes. First of all, a distinction must be made between documents written with the intention to deceive the readership regarding the author and those documents that were written without this intention. Furthermore, within these two groups, we have to differentiate between various kinds of pseudepigraphic documents.

Writings originally published without an author's name can belong to the pseudepigraphic documents written without the intention to deceive. ${ }^{7}$ Later on such documents could erroneously have been ascribed to a person who lived in earlier times and who was thought to have written similar writings. Ecclesiastes is a well-known example. ${ }^{8}$

In other cases, we are confronted with documents written by disciples of a famous philosopher (see Sint 1960:95-107). The highly esteemed teacher was named as the author, because his disciples intended to publish only what he had taught them or to write exactly as their teacher would have done. Students belonging to the school of Pythagoras are said to have published several works under their teacher's name. lamblichus and Porphyrius said of Pythagoras that he did not write anything down. Later on, his students realised that his wisdom and his knowledge were in danger of being lost. Therefore, they wanted to preserve the instruction of the famous teacher (Von Albrecht 1963 §158, 198. 252, 253; Des Places 1982 § 57, 58; Zeller 1923:127-128; Roloff 1988:37-38; 1996:55). These authors wrote with a certain ingenuousness in the sense of just documenting what the great philosopher had taught long before. They wanted to rescue from oblivion what they had learned. ${ }^{9}$ The authors of these

\footnotetext{
${ }^{7}$ See the survey of "Pseudepigraphie außerhalb der Fälschung," in Speyer (1971:32-44) and see Sint (1960:99-100).

${ }^{8}$ Cf Pokorny (1997:649) regarding Ecclesiastes. See Speyer (1971:39-41) and Schmeller (2001:187).

${ }^{9}$ Zeller (1923:114-115)said regarding "die neupythagoreische Schule": "Der Auktoritätsglaube dieser Schule brachte es mit sich, dass auch das, was in ihren Dogmen neu und eigenthümlich war, sich nicht als etwas neues gab, und in der Regel wohl von seinen Urhebern selbst nicht dafür gehalten wurde" (cf Von Albrecht 1963 § 253).
} 
pseudepigrapha did not try to hide themselves. They did not intend to deceive the readers and the readers did not consider Pythagoras as being the real author.

Plato's dialogues should perhaps also be mentioned in this regard. It is evident that at least part of the opinions expressed in these dialogues by Socrates ${ }^{10}$ originate from Plato himself. But it appears to be questionable whether such literary inventions can be considered as being deceptive. ${ }^{11}$ The same practice was continued in the documents published by later philosophers. Epistles written by order of a king or another authority also belong to this group (Speyer 1971:32-34). Secretaries and orators sometimes prepared documents for other persons because of their professional ability. Such documents were published under the name of the principals.

The other category, that of documents written with the intention to deceive the readers regarding the authorship is totally different (Sint 1960:115-118). The authors of such documents could be motivated by different purposes such as avarice (Speyer 1971:133-134), greed for religious power (Speyer 1971:146-149) or promotion of a specific opinion (Sint 1960:118; Speyer 1971:139-142; Schmeller 2001:188). ${ }^{12}$ I would like to furnish some examples. A certain Onomacritus, living in the sixth century $\mathrm{BC}$, is said to have inserted in the work of Musaeus a prophecy of his own. He was expelled from Athens because he claimed that a text written by himself originated from another person. ${ }^{13}$ Later on he lived at the Persian court, where he tried to obtain political influence by means of supposed prophecies about a Persian expedition against Greece. Anaximenes (fourth century $\mathrm{BC}$ ) is said to have written a book in which he slandered the

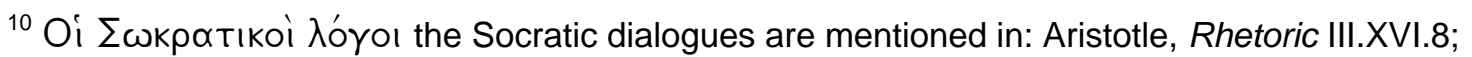
Aristotle, Poetica 1447b.

${ }^{11}$ L Robin (1970:XXI) explains it as follows: "Se considérant enfin luimême comme le continuateur de l" oeuvre de Socrate, il pouvait se croire en droit de lier comme il l' a fait l' histoire de sa propre pensée à ce qu' il savait du passé de celle de son maître, en prolongeant l' une par l' autre. Personne autour de lui ne pouvait s' y tromper: la fiction était évidente pour tous les lecteurs, et Platon n" avait pas besoin de chercher à la dissimuler."

${ }^{12}$ T Schmeller (2001:188) puts it as follows: "Pseudepigraphie war ein Instrument [...] zur Unterstützung der eigenen Position."

${ }^{13}$ Herodotus, Histories 7.6 (cf Sint 1960:52). 
people of Athens, Sparta and Thebes. But he mentioned as author a certain Theopompus, whom he despised (cf Pausanias, VI.18.5). Consequently, Theopompus fell into disfavour. The author of the so-called letter of Aristeas tried to demonstrate in his epistle that "King Ptolemy and his envoy Aristeas respected and praised the Jewish Law" and that the Greek translation of the Old Testament was "a genuine equivalent of the Torah" (Vermes, Millar \& Goodman 1986:679; Sint 1960:81). This Aristeas is mentioned as a top official of Ptolemy II, but is not known from history. Although there is no certainty regarding the date of this epistle, it certainly was written later than the middle of the third century, the time during which Ptolemy II lived. It is thus evident that this epistle of Aristeas is a forgery (Speyer 1971:163; Sint 1960:80-81). A certain Diophantus wrote a letter with the intention of slandering the sons of Herod the Great, Alexander and Aristobulus. In it, a planned assault on Herod's life is mentioned. This letter is purported to have been written by Alexander. Later on this Diophantus was put to death for similar crimes (Josephus, De Bello Judaico I.528-529; Antiquitates XVI, 319). Another example is the spurious thirteenth epistle of Plato that may have been written with the purpose of depicting Plato as an avaricious person (Speyer 1971:140). From these examples it should be clear that the forging of documents with the intention to deceive the readership was not considered to be acceptable. ${ }^{14}$ Furthermore, the example of Onomacritus suggests that the mere use of another person's name was sufficient to bring someone to court.

\section{TO WHICH OF THESE CATEGORIES DO THE PSEUD- EPIGRAPHIC PAULINES BELONG?}

It would be very helpful if it were possible to classify the pseudepigraphic Paulines in one of the abovementioned categories. They are not literary inventions, written with the purpose of earning money or to please the readership, nor are they documents written in order to preserve an older tradition

\footnotetext{
${ }^{14} \mathrm{Cf}$ also the denunciation of adding or cutting out phrases out of epistles in: Eusebius, Historia Ecclesiastica IV, 23,12. Concerning the falsification of Origenes" books, see Rufinus, De Adulteratione librorum Origenis, in SC 464, 285-323.
} 
taught by a famous teacher (Speyer 1971:177). The authors wrote these epistles in order to give their answers to problems that arose in the churches. But they pretended to give Paul's answers. These documents belong to a specific time, written with the intention of interfering in the current church situation. By using the name of a well-known apostle, these pseudepigraphic epistles would gain much more authority. It is sometimes argued with respect to "Pauline" pseudepigrapha that the authors of these letters made the Pauline teaching suitable to new circumstances. The studies by Brox $(1969,1975)^{15}$, Meade $(1986)^{16}$, Roloff $(1988)^{17}$ and Marshall $(1999)^{18}$ can be mentioned in this regard. Despite some minor differences, they all argue that a later author wanted to give Pauline answers to urgent questions. They founded their thesis on what they thought to be a more or less similar practice in older times, especially in the schools of philosophers (Brox 1975:110; Roloff 1988:38; Marshall 1999:84; cf also Schenke \& Fischer 1978:233-247). ${ }^{19}$ But students in these schools tried to write just as their teachers would have done ${ }^{20}$, they did not want to interfere in current circumstances. Other philosophical documents were written with the intention of merely preserving an older tradition, though new ideas were often unwittingly included (Speyer 1971:34-35). These authors did not want to make the instruction of their teacher topical, nor did they write their documents to support people or communities in difficult circumstances, they only intended to preserve

\footnotetext{
${ }^{15}$ Brox (1969:62): "die apostolische Überlieferung in die Jetztheit hinein zu interpretieren" (see also Brox 1975:119).

${ }^{16}$ With regard to the Pastorals, Meade (1986:131) speaks about "a conscious effort to actualize Pauline tradition."

${ }^{17}$ Roloff (1988:38): "Der Verf. unterstellt das, was der Kirche seiner Gegenwart [...] gesagt werden muß, der Autorität des Paulus."

${ }^{18}$ Marshall (1999:92): "fresh formulations of Pauline teaching to take account of the changing situation."

${ }^{19}$ Meade (1986:195) concluded, despite an earlier (10-11) repudiation of the "school"-theory: "The only possible Pauline pseudepigrapha that may be due to a "school", [...] is the Pastorals." For Galenus' remarks on Christians as a school, see Schmeller (2001:47.94.180).

${ }^{20}$ H R Balz (1969:414) puts it as follows: "zahlreiche Schulprodukte im Stil und nach dem Geist der großen Vorbilder."
} 
old traditions for subsequent generations. ${ }^{21}$ The purpose of pseudepigraphic Paulines is very different. The authors of these epistles wanted to support the young churches in rather difficult times. They discussed the specific problems the young churches were confronted with. These epistles were meant to assist the churches in their struggle with the difficulties of their times.

One of the problems of the day pertained to organising the young church (see the remarks on that subject in the Pastorals). Another one was related to the delay of the Day of the Lord. The author of 2 Thessalonians tried to explain in the second chapter of his epistle why it would take longer before the Day of the Lord would arrive (cf also 2 Pt 3:8-9). Though Paul is mentioned in the prescript as the author of 2 Thessalonians, we can perhaps even refer to it as "eine Korrektur an Paulus" (Müller 1988:67; cf also Koester 1990:441-458), a correction of Paul.

The authors of these epistles used Paul's name, but they gave their own answers, which were in some cases at least, rather different to those given by Paul himself earlier on. It has to be said that they wittingly gave other answers than the purported author did before, because the new circumstances required new answers. To them (these authors) it was of vital importance to win the theological struggles of the time and for this reason they made these epistles seem to originate from Paul. To lend credibility to the authenticity of their epistles, certain details were inserted that should support this claim. ${ }^{22}$ In this way, they could achieve their purpose, i e that their epistles would get authority in the churches. The example of Plato's dialogues does not constitute a parallel. We must consider these writings as literary inventions, not meant to interfere in current circumstances. The students and readers of Plato's dialogues probably knew that Socrates' words were not spoken by him in real life. ${ }^{23}$ The documents

\footnotetext{
${ }^{21}$ Marshall (1999:83) speaks of "Preserving the Pauline Tradition."

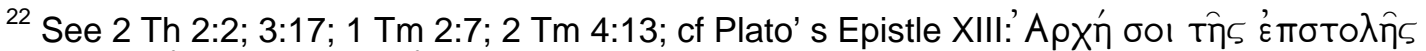
" that it is really an epistle of mine."

${ }^{23}$ Schmeller (2001:247) argues that some people may have known about the pseudepigraphic character of the Pastorals; it is according to Schmeller (2001:252), evident that the author of 2 Thessalonians tried to hide himself.
} 
written by pupils of Pythagoras do not present a proper parallel either. The authors of these documents did not use the name of the famous philosopher in order to promote their own points of view or at least they did not intend to do so. They intended to write down the statements of their teacher in order to save them from oblivion. That is not the case with the New Testament pseudepigrapha. The authors of these epistles did not intend to preserve the teachings of the persons mentioned in the prescript. With respect to Paul there was not even any need to do so. Paul himself wrote much more than we find in the six pseudepigraphic "Pauline" epistles together. The authors of the New Testament pseudepigraphic epistles wanted to implement their opinions in the churches. In order to achieve their purpose, they deliberately used a famous predecessor's name. This means that these epistles cannot be considered as produced by students in honour of a well-known teacher. Nor were they written to defend the tradition of a certain school. The purpose of these epistles was to promote a specific theological opinion and to organise the young church. In order to achieve this, they made these epistles seem to originate from a well known person who lived some decades earlier. Such writings belong to the same category as other pseudepigraphic documents meant to influence the public opinion or to implement certain rules. ${ }^{24}$

\section{WERE PSEUDEPIGRAPHIC EPISTLES ACCEPTABLE IN THE CHURCHES?}

We should examine the acceptance of pseudepigraphic documents in the Christian churches of the first and the second centuries. At the time, it was considered to be legal to use "his master's voice" in the case of a student writing down what was thought to be the inheritance of a deceased teacher. But this is not the case with the New Testament pseudepigraphic writings. The discussion concerns epistles. And writing epistles under another person's name with the intention of suggesting that they originated from a famous predecessor was not

\footnotetext{
${ }^{24}$ See the examples given in Speyer (1971:139-142). Balz (1969:431) classified the Pastorals under "Tendenzfälschungen".
} 


\section{Pseudepigraphic Paulines in the New Testament}

considered as being acceptable. The examples of Onomacritus and Diophantus have already been mentioned. An "innocent" example is mentioned by Tertullianus. He wrote that a certain presbyter in Asia Minor published under Paul's name and was therefore discharged as presbyter. This was not because of heresies. From these examples we learn that forging epistles was punishable.

The authors of the pseudepigraphic epistles must have been aware of the fact that their actions were considered to be illegal, but they managed to remain undiscovered. We have to regard them as forgeries, however noble the intention of the authors was. And the church leaders of the first and the second centuries certainly did not wittingly accept epistles that were written under someone else's name. Accepting such documents would really have been rather unusual. But these epistles remained unexposed as pseudepigraphic documents. ${ }^{25}$ The theory that pseudepigraphic epistles were acceptable to church officials is not correct. If such theory were true, we could then even ask why authors such as Ignatius and Polycarpus did not write under Paul's name. ${ }^{26}$ We have seen that centuries earlier, certain authors wrote under someone else's name, but if it was done with the intention to deceive the readership such action was condemned. This was even true in the case of "innocent" forgeries by Onomacritus or, later on, by the presbyter mentioned by Tertullianus. The authors of such epistles wrote with the intention of exercising influence in any way possible. Sometimes they achieved their purpose, as is the case with the authors of the New Testament pseudepigraphic epistles. Other epistles were exposed as pseudepigrapha, in which case they lost their influence.

How could it be that some pseudepigraphic epistles remained unexposed? The correspondence between Jesus and Abgar, for instance, was considered as being authentic by Eusebius (Historia Ecclesiastica I.13; II.1.6-8), although nobody before him seems to have had knowledge about this interesting

\footnotetext{
${ }^{25}$ E E Ellis (2001:28-29) puts it as follows: "Only when the deception was successful were they admitted for reading in church, and when they were found out, they were excluded" (cf Schmeller 2001:186-187).

${ }^{26}$ With respect to Polycarpus this question is all the more fascinating as Polycarpus is sometimes mentioned as possible author of the Pastorals (see Brox 1969:57).
} 
document. And even the correspondence between Paul and Seneca was assessed as being authentic for some time (Römer 1989:44-50). Jerome was the first person to mention these epistles. (De Viris Illustribus 12). It would take some centuries before these epistles were exposed as pseudepigrapha (Berry 1999), ${ }^{27}$ implying that the dignitaries were not always attentive to pseudepigraphic documents.

\section{CONCLUSION}

I conclude that authors of New Testament pseudepigraphic epistles consciously wrote under another person's name. They resorted to this emergency measure in order to influence the theological discussions of their time and in order to organise the young church in the way they thought it should be done. Under the name of Paul their epistles received much more authority than they would have under their own name. These epistles have nothing to do with the documents written by some scholars in order to honour their teacher or in order to preserve the tradition they had taught. On the contrary, they belong to the category of forgeries. Their authors tried to mask themselves and managed to do so. The use of Paul's name was improper. If these epistles had been known as pseudepigraphic documents, they would not have been accepted for use in the church. The authors of these epistles thought that writing under the name of a well-known person offered the best possibility of supporting the churches and of implementing new rules in a new time. This procedure made it much more probable that they would reach their purpose: namely building the church according to their views. ${ }^{28}$

\footnotetext{
${ }^{27}$ By regarding this correspondence as authentic, I would be an exemption.

${ }^{28}$ It is beyond the scope of this article to deal with the consequences therof for the canon. Recently A D Baum (2001:191) wrote: "Entweder das altkirchliche Offenbarungs- und Kanonverständnis, das von der Normativität ganzer Schriften ausgeht, wird zugunsten des Konzepts eines Kanons im Kanon aufgegeben. Oder man schließt, falls man dieses Konzept für undurchführbar hält [...] die Kanonizität gefälschter Schriften aus." In my opinion these two topics should not be linked. Pseudepigrahy is a historical problem and the canonicity is a matter of our belief.
} 


\section{Works consulted}

Balz, H R 1969. Anonymität und Pseudepigraphie im Urchristentum. ZThK 66.

Baum, A D 2001. Pseudepigraphie und literarische Fälschung im frühen Christentum. Tübingen: Mohr. (WUNT 2. Reihe 138.)

Berry, P 1999. Correspondence between Paul and Seneca AD 61-65. Lewiston: Mellen. (Ancient Near Eastern Texts and Studies 12.)

Brox, N 1969. Die Pastoralbriefe, 4.Aufl. Regensburg: Pustet. (RNT 7.2.)

Brox, N 1975. Falsche Verfasserangaben: Zur Erklärung der frühchristlichen

Pseudepigraphie. Stuttgart: Katholisches Bibelwerk. (Stuttgarter Bibelstudien 79.)

Collins, R F 1988. Letters that Paul did not write. Wilmington: Glazier. (Good News Studies 28.)

Des Places, E 1982. Porphyre: Vie de Pythagore. Paris: Les belles lettres.

Ellis, E E 2001. History \& interpretation in New Testament perspective. Leiden: Brill. (Biblical Interpretation Series 54.)

Koester, H 1990. Apocalyptic schemata of 2 Th, in Collins, R F (ed), The Thessalonian Correspondence. Leuven: Peeters. (BEThL 87.)

Klauck, H-J 1998. Die antike Briefliteratur und das Neue Testament. Paderborn: Schöningh.

Klauck, H-J 1998. Die antike Briefliteratur und das Neue Testament. Paderborn: Schöningh.

Marshall, I H 1999. The pastoral epistles. Edinburgh: Clark. (ICC.)

Meade, D G 1986. Pseudonymity and canon: An investigation into the relationship of authorship and authority in Jewish and earliest Christian tradition. Tübingen: Mohr. (WUNT 39.)

Müller, P 1988. Anfänge der Paulusschule. Zürich: Theologischer Verlag. (AthANT 74.) Pokorny, P 1997. s v Pseudepigraphie, I. TRE 27. Berlin-New York.

Robin, L 1970. Phédon. $11^{\text {th }}$ ed. Paris: Les Belles Lettres. Platon. (Oeuvres complètes IV.1.)

Roloff, J 1988. Der erste Brief an Timotheus; Neukirchen-Vluyn: Neukirchener. (EKK $\mathrm{XV}$.)

Roloff, J 1996. s v Pastoralbriefe. TRE 26. Berlin-New York.

Römer, C 1989. Der Briefwechsel zwischen Seneca und Paulus, in Schneemelcher, W (Hrsg), Neutestamentliche Apokryphen, II. 5.Aufl. Tübingen: Mohr.

Schenke, H-M \& Fischer, K M 1978. Einleitung in die Schriften des Neuen Testaments, I: Die Briefe des Paulus und Schriften des Paulinismus. Berlin: Evangelische Verlagsanstalt.

Schmeller, T 2001. Schulen im Neuen Testament? Freiburg: Herder. (HBS 30.) 
Sint, J A 1960. Pseudonymität im Altertum. Innsbruck: Wagner. (Commentationes Aenipontanae 15.)

Speyer, W 1971. Die literarische Fälschung im heidnischen und christlichen Altertum. München: Beck. (Handbuch der Altertumswissenschaft I.2.)

Verhoef, E 1996. De brieven aan de Tessalonicenzen. Kampen: Kok.

Verhoef, E 2002. Pastorale brieven. Kampen: Kok.

Verhoef, E [2003]. Towards a theory to determine the authenticity of the "Paulines": The Journal of Higher Criticism. (Forthcoming.)

Vermes, G, Millar, F, Goodman, M 1986. The history of the Jewish people in the age of Jesus Christ, III.1. Edinburgh: Clark.

Von Albrecht, M 1963. lamblichus: Pythagoras. Zürich: Artemis.

Zeller, E 1923. Die Philosophie der Griechen in ihrer geschichtlichen Entwicklung, 3.2. 5.Aufl. Leipzig: Reisland. 